\title{
Usikkert efterår i Libanon
}

\section{Peter Seeberg}

\section{Den libanesiske ministerpræsident Fouad Siniora offentliggjorde i midten af juli sin nye regering, der spås en usikker fremtid}

På trods af attentatet på Libanons ministerpræsident Rafik Hariri den 14. februar 2005, de mange andre bomber mod politikere, journalister og bombesprængninger mere eller mindre tilfældige steder i Beirut, der i hele foråret og sommeren har plaget såvel Beiruts indbyggere som turisterne, er der en proces i gang, der synes at videreføre den politiske linje, som Rafik Hariri repræsenterede. Samtidig peger en udtalt politisk uro i retning af en modsætningsfyldt situation, hvor den kontroversielle Hariri er blevet en rolle til del, som han aldrig nåede, mens han var i live.

Der er ingen tvivl om, at Hariri efter sin død har opnået status som en landsfaderlig skikkelse med stor folkelig opbakning. Mordet på den internationalt kendte multimilliardær, ministerpræsident i det meste af post-borgerkrigsperioden - han blev dræbt ved en bombesprængning, da han i en bilkortege var på vej langs den genopbyggede havnefront - gav anledning til omfattende protestdemonstrationer. Demonstrationerne var udtryk for sympati med Hariris efterladte og vrede mod de ukendte gerningsmænd, men de udviklede sig desuden til folkelige protester vendt mod den syriske tilstedeværelse i landet og mod de Syrien-venlige politikere i det libanesiske parlament.

Det konfessionelle system tilsiger en ligelig fordeling af ministre og af de 128 mandater i parlamentet. Samtidig skal posterne som præsident, ministerpræsident og parlamentsformand fordeles således, at de tre poster går til hhv. en kristen maronit, en sunnimuslim og en shiamuslim. Opbakningen til de politiske partier og til staten og nationen har været et centralt tema i libanesisk politik siden borgerkrigens afslutning. I de første år - de tidlige 1990 'ere - handlede det om at komme økonomisk på fode. Denne proces er langt fra afsluttet. Den politi- 
ske udvikling har været kendetegnet ved store modsætninger, ikke mindst på personniveau. Forholdet mellem den magtfulde Hariri og den siddende præsident - fra 1989 til 1998 Elias Hrawi og fra 1998 Emile Lahoud - er et væsentligt omdrejningspunkt i denne proces, med den syriske præsident som en afgørende med- og modspiller.

To dage efter mordet på Libanons sidste præsident under borgerkrigen, René Mouawad, den 22. november 1989 blev Elias Hrawi valgt til posten. Der blev dannet en ny regering ledet af Salim Al-Hoss. General Aoun, der havde proklameret frihedskrig mod Syrien, blev erstattet som general af Emile Lahoud - samme Lahoud, der 9 år senere blev præsident. Elias Hrawis præsidentperiode blev således forlænget tre år ud over den ordinære periode på seks år.

Da Emile Lahoud blev indsat som præsident 24 . november 1998, var det blandt andet med et udtrykkeligt løfte om at gøre noget ved den ineffektive og korrupte offentlige sektor i Libanon. Sammen med Salim Al-Hoss, der 1. december 1998 afløste Hariri som premierminister, indledte han en lang række politiske omrokeringer, der ifølge regeringens politiske modstandere nærmest havde karakter af udrensninger. Allerede den nye regering, der bestod af 16 ministre, signalerede nye tider, for hensyn til konfessionel og regional sammensætning, som er nedfældet i Libanons forfatning, var stort set det eneste element i den nye regering, man kunne nikke genkendende til.

I de følgende måneder blev utallige embedsmænd forflyttet eller simpelthen fyret. Set fra oppositionens side lignede det en klapjagt på den administration, der var blevet opbygget under Hariri, og Libanon blev kastet ud i en langvarig politisk krise. De spørgsmål, der trængte sig på, var for det første, om Libanons problemer skyldtes den uduelighed og korruption, man havde arvet fra det forrige styre, og for det andet, hvad der skulle til, for at Libanon kunne komme videre i den rekonstruktionsproces, som den politiske krise truede med at sætte i stå.

Korruption udgjorde en vigtig del af det politiske problem i Libanon. Det lignede til forveksling cykelsportens dopingproblem: stort opsatte skandaler i medierne, nogle få der blev hængt ud, udbredt diskussion om nødvendige opstramninger, mens de fleste sad tilbage med en fornemmelse af, at der ikke for alvor blev gjort noget ved sagen. Det særlige ved korruptionsproblemet i Libanon var en kombination af, at der i løbet af borgerkrigen udvikledes en sort økonomi, som fortsat fandtes, og at styret ikke formåede at gøre op med dette. Et system af returkommission og uformelle aftaler var et vedvarende vilkår og blev måske endda på nogle punkter udbygget i "fredsårene".

Dertil kom, at der var etableret il- 
legale formuer og mere eller mindre mafialignende strukturer, som det i sagens natur var vanskeligt at komme af med - specielt i en region, hvor bestikkelse er så udbredt som i Mellemøsten. Derfor var tiltroen til Lahoud og al-Hoss' muligheder for at rydde op begrænset. Så meget større var overraskelsen, da en tidligere olieminister i marts 1999 blev fængslet, anklaget for at have tilegnet sig og solgt olie, som ankom til Beirut havn - altså ganske enkelt stjålet af landets olieimport. Senere fulgte sager mod andre politikere og embedsmænd, som havde gjort sig skyldige i affærer, hvor egen vinding tydeligt var hovedinteressen.

\section{Hariris offensiv}

Men Hariri affandt sig ikke med de mange anklager mod hvad der i høj grad blev betragtet som hans personlige netværk. Fra Hariri fratrådte i december 1998 og til han igen blev premierminister i november 2000, benyttede han enhver lejlighed til at kritisere, hvad Lahoud og Hoss foretog sig. Det forekom bemærkelsesværdigt, at det kunne lade sig gøre, for der var næppe tvivl om, at lederne i Damaskus hele tiden stod bag Lahoud, som i sin tid blev indsat på initiativ af Syriens præsident Assad.

Der var flere forklaringer på Hariris vedvarende offensiv. For det første var der ganske enkelt noget om det, han sagde. En stor del af hans kritik rettede sig mod den politik, den nye regering lancerede for at løse Libanons økonomiske vanskeligheder, som især var kendetegnet ved et stort og voksende offentligt underskud. Den del af kritikken forekom berettiget - der var tale om ret perspektivløse offentlige besparelser, som selv ifølge regeringens egne forudsigelser kun marginalt ville påvirke Libanons økonomi.

For det andet handlede det om at vinde offentligheden over på sin side: På den ene side forsøgte Hariri at overbevise den libanesiske offentlighed om, at regeringen for så hårdt frem mod (hans) tidligere embedsmænd og ministre for at dække over egen uformåenhed. $\mathrm{Og}$ på den anden side forsøgte regeringen utvivlsomt at kaste skylden på den foregående regering for at dække over, at de ikke kunne finde på en overbevisende plan for at forbedre Libanons situation.

Og for det tredje tydede meget på, at Hariri planlagde at vende tilbage som premierminister så hurtigt, det kunne lade sig gøre. Det skyldtes mest et sammentræf af uheldige omstændigheder, at han i december 1998 ikke videreførte regeringen, og hans reaktioner tydede klart på, at han havde fortrudt den exit, der kunne være undgået.

At en politisk tilbagevenden ikke kunne udelukkes, bekræftedes af, at den syriske præsident Hafiz al-Assads søn, Bashar Assad, i et interview udtalte, at Hariris tilbagevenden til 
magten ikke var umulig, det var noget, Libanons politiske institutioner skulle afgøre. Det var opsigtsvækkende, smukke toner fra en politisk instans, der gennem årtier efter forgodtbefindende havde udskiftet landets politiske ledere.

Et forhold, som selvsagt var helt upåvirket af Libanons politiske konflikter, men som ikke desto mindre havde stor betydning for Libanons økonomi, var oliepriserne på det internationale marked. Stigende oliepriser betød stigende indtægter for GCC-landenes emirer og fyrster, og det havde konsekvenser for deres investeringslyst, hvilket meget markant kunne mærkes i Beirut i de perioder, der var tale om. Udenlandske investeringer var i dobbelt forstand guld værd for et styre, der sloges med underskud i forholdet til udlandet, og de Golf-baserede investeringer i Beiruts genopbygning betød en forbedring af den libanesiske økonomi. På den måde var der en nær sammenhæng mellem pengerigelighed i Golfstaterne, succes for projekt "rekonstruktion af Beirut/ Libanon" og for, hvor sikkert den siddende regering sad i sadlen.

Det var vigtigt for at sikre udenlandske investeringer i Libanon, at investorerne havde vished for, at pengene ikke forsvandt i lommen på uhæderlige embedsmænd eller i urealistiske luftkasteller. Dette havde ikke hele vejen rundt været tilfældet. Set i det lidt større perspektiv drejede korruptionsproblemet sig dybest set om, at Libanon var på vej tilbage til normale tilstande. Med til at være et moderne "vestligt" land hører en ikke-korrupt og velfungerende offentlig administration, og måske var det i virkeligheden det, der gik op for de politiske ledere i Libanon. Beirut kunne ikke genindtage en position som Mellemøstens vestorienterede metropol med en offentlig sektor, der fungerer som i en bananrepublik.

Den nye regering, der blev indsat i 1998, annoncerede yderligere ændringer i ministerierne, primært i form af sammenlægninger af beslægtede kontorer. Onde tunger i Beirut hævdede, at det simpelthen var nødvendigt på grund af de mange afskedigelser. Desuden ville en række udsatte korruptionssager blive taget op igen, når parlamentets ordinære samling fandt sted. Her skulle der bl.a. tages stilling til ophævelse af en række parlamentsmedlemmers immunitet.

Det store spørgsmål var, om regeringen kunne overleve den fortsatte politiske krise. Det forekom sandsynligt, at en eller anden form for ændring var undervejs. Den drusiske leder, Walid Jumblatt, kritiserede den nye regering for at centralisere magten, og anklagede specielt Lahoud for at være alt for dominerende og selvrådig. Men Lahoud havde støtte fra Damaskus og forekom urørlig. En mulig udgang var derfor, at Salim Hoss ofredes for at lægge en dæmper på kritikken, og 
dette kunne foregå ved, at en ny regering blev etableret med Hariri tilbage som premierminister. Denne lærte så måske af denne komplicerede udvikling, at det hører med til moderne politik ikke at fylde ministerier op med sine politiske venner.

For Libanon var situationen alvorlig. Landet kunne ikke vedvarende holde til i den grad at være i politisk undtagelsestilstand - de politiske modsætninger kunne blusse op igen og udvikle sig til blodige konflikter.

\section{Modstand imod Syrien}

Da det i november 2004 kom til nyvalg på præsidentposten, så det umiddelbart ikke ud til at blive kontroversielt, at den syriske præsident Bashar al-Assad besluttede at sætte igennem over for libaneserne, at den libanesiske præsident Emile Lahoud skulle have forlænget sin præsidentperiode med tre år.

Men det skulle komme til at gå ganske anderledes. Først førte en usædvanlig alliance i FN mellem Frankrig og USA til vedtagelsen af en Syrien-kritisk resolution (FN's Sikkerhedsråds Resolution 1559 af 2. sept. 2004), vendt mod syrisk indblanding i Libanon. Og siden gav forlængelsen anledning til endnu en indenrigspolitisk krise i Libanon. Spørgsmålet var, om Syrien dermed svækkede Lahoud og sin potentielle indflydelse i Libanon og i regionen?

Denne udvikling tog sin begyndelse i det tidlige efterår 2004, hvor der var livlig politisk aktivitet i Libanon. Det begyndte med, at Bashar al-Assad offentligt erklærede, at valget af ny præsident var et internt libanesisk anliggende. Flere maronitiske politikere meldte sig på banen som mulige kandidater, men kort tid efter aflagde flere ledende libanesiske politikere, bl.a. tidligere ministerpræsident Salim al-Hoss, besøg i Damaskus. Måske skyldtes besøgene i Damaskus, at den politiske situation i Libanon efterhånden så ud til at blive noget broget, og da den syriske udenrigsminister Faruq Shara aflagde besøg i Beirut og afholdt uofficielle, lukkede møder med Lahoud, var det klart, at noget var under opsejling, som var uden for Libanons egen selvbestemmelsesret.

Da så yderligere Hariri i forlængelse af samtaler med Bashar al-Assad og den syriske sikkerhedschef i Libanon, Rustum Ghazali, indkaldte til regeringsmøde og på baggrund af dette møde, der varede 15 minutter, foreslog, at Lahoud fik forlænget sin status som præsident for en periode på tre år, var der ikke længere noget tvivl. Syrien havde endnu en gang sat sin magt igennem og tvunget Hariri til at acceptere en løsning, der var ham imod - ikke mindst på baggrund af, at Hariri i en række offentlige ytringer havde gjort sig til talsmand for, at Lahoud under ingen omstændigheder kunne fortsætte som præsident. Hariri bar sig ad som en klog politisk pragmatiker, og lod sig i første omgang 
tilsyneladende ikke mærke med at være blevet banket på plads.

Den syriske præsident, Bashar alAssad, havde med forlængelsen af Lahoud måske umiddelbart sikret den syriske indflydelse i Libanon i nogle år. Men handlingen havde på grund af den spændte situation i regionen tiltrukket sig opmærksomhed og fik - indirekte via resolution 1559, direkte på grund af Irak-krisen - amerikanerne til yderligere at lægge pres på Syrien. Syrien havde med en uheldig manøvre svækket sin udenrigspolitiske handlefrihed.

Den syriske manøvre med at forlænge en præsidents regeringsperiode var set før og var måske ikke en større overraskelse. Det nye bestod for det første i, at det som nævnt denne gang fra både libanesisk og syrisk side var meldt ud, at de dage var forbi, hvor den slags kunne finde sted. For det andet med hensyn til den bevågenhed, som handlingen snart blev til del i international sammenhæng, specielt hvad angår reaktionen i FN. Og for det tredje fordi begivenheden foregik på et tidspunkt, hvor der på grund af den kritiske situation i Irak var god grund til at holde øje med alle mulige former for politiske signaler.

Beslutningen om at forlænge Lahouds præsidentperiode med tre år blev den 3. september 2004 vedtaget med stor majoritet i Parlamentet i Beirut. Det var også interessant, i lyset af amerikanske påstande om tætte relationer mellem Hizbollah og
Syrien, at se, at alle 12 Hizbollahtilknyttede parlamentsmedlemmer stemte for at forlænge Lahouds præsidentperiode, idet de henviste til, at Lahoud jævnligt havde givet udtryk for støtte til deres aktiviteter.

\section{Hizbollah}

I de internationale medier var der forholdsvis roligt omkring begivenhederne i Libanon, mens det derimod vakte stor opmærksomhed, at Frankrig og USA fandt sammen i en, i det mindste hvad Mellemøsten angår, sjældent set alliance i FN - og med vedtagelsen af resolution 1559 krævede, at alle ikke-libanesiske tropper blev trukket ud af Libanon, at alle forsøg på at øve indflydelse på libanesisk politik ophørte og at alle militser i Libanon - adressaten hér var Hizbollah - blev afvæbnet.

Den libanesiske reaktion udeblev ikke. I et brev til Kofi Annan protesterede man fra officiel libanesisk side, idet Lahoud samtidig gik i de internationale medier med et budskab om, at FN repræsenterede dobbeltmoral ved ikke at protestere mod Israels overskridelser af internationale regler. Og Hizbollahs generalsekretær, Hassan Nasrallah, gik mere direkte til værks med en erklæring om, at resolutionens krav om afvæbning af militser var et krav, der stammede fra Israel. Med vedtagelsen af resolution 1559 var Israelkrav ifølge Nasrallah således skrevet direkte ind i en sikkerhedsrådsreso- 
lution, hvilket efter Nasrallahs opfattelse repræsenterede den størst tænkelige uhyrlighed.

En talsmand for Syrien i FN udtalte, at den ubestemte (der stod ikke eksplicit Syrien i resolutionen) henvisning til, at ikke-libanesiske tropper skulle trækkes ud af Libanon, drejede sig om Israels fortsatte tilstedeværelse i Sheeba Farms-området ved Golan. Dette var mest en forudsigelig retorisk finte, men det hørte med til historien, at resolutionens ukonkrete karakter hang sammen med en indsats fra Ruslands og Kinas side for at skabe en lidt mere balanceret resolution end den oprindeligt foreslåede version, hvori såvel Syrien som Hizbollah blev nævnt ved navn. Netop hvad angår Hizbollah var det en yderligere vanskelighed, at Frankrig ikke anså dem for at være en terrororganisation, hvilket USA gjorde.

Hvad USA angår, handlede det imidlertid ikke om Libanon og den libanesiske præsidents betydning for forholdet mellem Israel og Syrien. Det var et sekundært problem. Fokus var derimod på Syrien og det var den syriske villighed til at samarbejde om Irak-spørgsmålet, der var afgørende for USA. Derfor var den amerikanske viceudenrigsminister, William Burns, i september 2004 i Damaskus med en omfattende stab, som bl.a. skulle forbedre grænsekontrollen mellem Syrien og Irak.

Den syriske manøvre med at sikre Lahoud en præsidentperiode til var i det perspektiv mindre betydningsfuld, og snarere end at se resolution 1559 som en alvorlig trussel mod Syrien var der grund til at hæfte ved, at det lykkedes at forene amerikanske og franske Mellemøst-synspunkter i FN efter mere end et års uenighed, uden at der var det store perspektiv i FN-aspektet af problemstillingen. At et mindre kontingent syriske tropper blev trukket ud af Libanon $i$ anden halvdel af september, skulle næppe ses som et resultat af det aktuelle fransk-amerikanske pres, men som en del af en mere langsigtet plan, der langsomt reducerede antallet af syriske tropper i Libanon. For amerikanerne var Irakspørgsmålet langt vigtigere.

De storpolitiske perspektiver var ikke så vidtrækkende, og formentlig var USA og Frankrig glade for en mulighed for at lægge nogle af de senere års stridigheder bag sig. $\mathrm{Og}$ selv om der fortsat befandt sig en libanesisk, maronittisk domineret lobby i Paris, var det ikke sandsynligt, at spørgsmålet skyldtes uofficielle kontakter mellem Hariri og den franske regering - med henblik på at mindske den syriske indflydelse i Libanon og begrænse Lahouds magt.

Denne antagelse, der blev fremsat $\mathrm{i}$ internationale medier, haltede også en smule på baggrund af, at Lahoud i god overensstemmelse med den libanesiske forfatning var kristen maronit, mens Hariri tilhørte det sunnimuslimske mindretal. For sammensværgelsesteorien talte, at 
Hariri havde gode kontakter til den franske præsident Chirac.

Forklaringen på den bemærkelsesværdige historie var tilsyneladende, at den syriske præsident på baggrund af en lidt vanskelig situation i Libanon, hvor politisk tumult syntes under opsejling, valgte en nem løsning, som han, og de libanesiske ledere han konsulterede, vurderede ikke ville give anledning til den store polemik. Dette skulle imidlertid vise sig at være en politisk faux pas. I første omgang så det ud til at lykkes, men siden skærpedes de indenrigspolitiske modsætninger.

Det handlede dels om nogle af de traditionelle modsætninger i libanesisk politik, hvor specielt den drusiske leder, Walid Jumblatt, benyttede lejligheden til meget kraftigt at kritisere Lahoud for i alt for høj grad at optræde som marionet i forhold til syriske interesser. Jumblatt kaldte offentligt Lahoud "et viljesløst spøgelse". Kritikken formåede siden at samle bredere opbakning og skabte en mediestorm, der opererede med en hidtil uset frihed i de libanesiske medier i henseende til kritik af såvel Lahoud som af den syriske indflydelse i Libanon.

Det centrale syntes at være personspørgsmålet. Konflikten i toppen af den libanesiske ledelse mellem præsident Lahoud og ministerpræsident Hariri spidsede til, og spekulationerne drejede sig om den regeringsomdannelse, der skulle foregå i november 2004. De efterfølgende uger gik med konsultationer med Damaskus og opfølgende møder i Beirut, og i den forbindelse forekom Hariri at være kommet styrket ud af den indenrigspolitiske krise.

\section{Regeringens usikre fremtid}

Sammenhængen er ikke påvist, men det kan ikke afvises, at Hariri ved at sige fra i oktober 2004 over for forlængelsen af præsident Lahouds regeringsperiode fra 6 til 9 år har spillet højt spil med henblik på at realisere sin vision for Libanon og definitivt gøre sig selv til den helt afgørende politiske skikkelse i libanesisk post-borgerkrigshistorie. Givet er det, at han ved at melde sig ud af libanesisk politik i efteråret 2004 meget vel kunne tænkes at ville anlægge en landingsbane for sig selv som Libanons redningsmand efter valget i maj 2005. Dette blev håndfast forhindret med bombesprægningen i Beirut 14. februar 2005.

Spørgsmålet er, om der ud af den spændte situation kan opstå en national konsensus i libanesisk politik, eller om landet snarere bevæger sig mod en længerevarende politisk krise. Der er flere tegn på vanskeligheder. Umiddelbart står den Haririorienterede alliance stærkt med 2/3 af mandaterne bag sig, herunder druserne med Jumblatt i spidsen. Den libanesiske præsident Emile Lahoud, der som næunt fik sit mandat forlænget på syrisk initiativ, står svagt, men insisterer tilsyneladende 
fortsat på at have indflydelse på både regeringens sammensætning og den førte politik. Et udtryk for dette er, at hans svigersøn, Elias Murr, der den 12. juli overlevede et voldsomt attentatfors $ø g$, er blevet genindsat som forsvarsminister.

Murr står i lighed med Lahoud for en prosyrisk linje, og netop dette indebærer, at forklaringen på de mange attentater og mordfors $\varnothing \mathrm{g}$ kompliceres en hel del. Antydningerne af, at der kunne stå syriske agenter bag bombesprængningerne, dementeres i det mindste i dette tilfælde. Diskussionerne i Beirut om hvem der står bag, er således kendetegnet ved stor usikkerhed både hvad angår motivet til disse, og hvem der har ansvaret for dem.

Det forandrer imidlertid ikke noget ved, at sikkerhed er blevet det helt store tema, og at det ellers, i mellemøstlig sammenhæng, forholdsvis åbne libanesiske politiske liv, har forandret sig markant i løbet af 2005. Området omkring regeringsbygningen, det osmanniske "Grand Serail", er således forskanset med pansrede køretøjer og forsvarsværker med sandsække og opbud af soldater ligesom gaderne i det rekonstruerede downtown Beirut er afspærret med metalbomme og bevogtet af svært bevæbnede soldater.

Også Hizbollah opfattes i libanesisk politik som en del af oppositionen til Hariri-alliancen. De står stærkt i det nye parlament og har derfor fået en ministerpost. Porte- føljen, energi- og vandministeriet, er ikke nogen nem opgave. Det nationale Electricité du Liban (EDL) har enorme gældsproblemer og er ramt af korruptionsanklager, som vil være særdeles vanskelige at rydde op i.

De udenrigspolitiske aspekter af, at Hizbollah er kommet med i regeringen, er problematiske. At USA har meddelt, at man ikke vil kommunikere med en minister, der i amerikansk optik repræsenterer en mellemøstlig terrorbevægelse, er til at leve med, så længe man har givet udtryk for, at dette ikke gælder regeringen som sådan. Men udnævnelsen puster nyt liv i FN-resolution 1559, specielt hvad angår spørgsmålet om afvæbning af Hizbollah.

Haririrs søn Saad Hariri, der mødtes med Condoleezza Rice i juli i forbindelse med, at hun aflagde Libanon en kort visit, sagde i et interview med CNN, at Libanon i en vanskelig politisk situation må have tid til at diskutere sine egne interne anliggender, men at det var hans opfattelse, at Hizbollah var parat til at diskutere disse spørgsmål. Siden har Hizbollahs Hassan Nasrallah gentaget de kendte synspunkter om nødvendigheden af kamp mod Israel. Det er tilsyneladende ikke lige nu tiden til at tage hul på de mere vanskelige spørgsmål i libanesisk indenrigspolitik.

I den tidlige sensommer blev en af borgerkrigens kendte skikkelser, LF-lederen Samir Geagea, løsladt efter 11 år i fængsel. Løsladelsen 
fandt sted på baggrund af en lov om amnesti vedtaget i parlamentet. Det var ventet, at løsladelsen ville give anledning til demonstrationer og eventuelt nye attentater eller lignende. Dette skete imidlertid ikke. Han blev i en militærkonvoj kørt direkte fra fængslet til Beirut lufthavn, hvorfra han blev fløjet til Frankrig - angiveligt med henblik på medicinsk behandling og restituering.

Tilsyneladende blev episoden søgt tiet ihjel af de ledende politiske skikkelser i libanesisk politik, men det forekommer tydeligt, at borgerkrigens spøgelser fortsat spiller en central rolle og kan udnyttes til at skabe indenrigspolitisk konflikt.

\section{Det belastede forhold til Syrien}

I sommeren 2005 var der omfattende uro i flere af de palæstinensiske flygtningelejre i Libanon. Især i den store Ain al-Hilweh-lejr i Saida, 40 $\mathrm{km}$ syd for Beirut, var der væbnede kampe mellem Fatah-folk og tilhængere af PFLP, ligesom der i andre lejre var demonstrationer og mindre konfrontationer. Der er ikke noget nyt i, at der er uro i Libanons flygtningelejre, men decideret væbnede konflikter forekommer trods alt ikke ofte.

En række eksterne årsager har fået skylden for sommerens uro i lejrene, den tilspidsede situation i Irak og konflikterne i forbindelse med den israelske tilbagetrækning i Gaza er blevet nævnt. Men også palæsti- nenserne har været indblandet i det belastede forhold mellem Libanon og Syrien, ikke mindst fordi en del af de palæstinensiske lejre befinder sig i fattige, ofte shiamuslimske byområder, hvor der desuden lever mange hundrede tusinde mere eller mindre legale indvandrere, hvoraf en meget stor del fra Syrien.

Siden attentatet på Hariri har mange af disse forladt Libanon, men der er fortsat et anspændt forhold mellem libanesere og syrere i Libanon. Ifølge Libanons The Daily Star blev 37 syrere dræbt og mange såret i ugerne efter mordet på Hariri. I nogle tilfælde havde disse mord karakter af lynchninger, og i nogle tilfælde var der også konflikter mellem libanesere og palæstinensere, som har bidraget til at skabe en ophedet stemning i lejrene.

De syriske reaktioner på den udbredte libanesiske kritik har bl.a. bestået $i$, at man blokerede grænseovergangene for libanesiske lastbiler. Dette gav anledning til enorme problemer og til store økonomiske tab for libanesiske eksportører og vognmænd. Forholdet opfattedes som så betydningsfuldt, at det blev nævnt for Condoleezza Rice i forbindelse med hendes besøg i Libanon, der herefter omtalte det i sin officielle tale efter møderne.

Blokaden blev først ophævet efter længere tids forhandlinger - fra syrisk side blev blokaden begrundet med frygten for, at der blev smuglet våben og terrorister til Syrien med 
henblik på videre transport til Irak. Desuden smed Syrien hundredevis af ingeniører og forretningsfolk ud af landet under henvisning til, at også de udgjorde en sikkerhedsrisiko - og i øvrigt, at deres papirer ikke var i orden.

Det har været en udbredt opfattelse i Libanon, at grænseblokaderne var en simpel hævnaktion fra det syriske regimes side - som tak for sidst for al kritikken af Syrien, herunder antydningerne af, at mordet på Hariri var begået på syrisk initiativ eller i det mindste, at man kendte til planerne herom i Damaskus. Et lyspunkt i den forbindelse er det trods alt, at den syriske præsident Assad på det seneste har løst problemet med de lange køer af lastbiler ved de syriske grænseovergange.

\section{Den negative udvikling siden valget}

Tilbage står, at den politiske situation i Libanon er mere end labil. Der er langt fra tale om nogen national enighed, men snarere om en situation, hvor de enkelte etniske og religiøse grupper forsøger at styrke sig selv med henblik på en usikker fremtid. De indenrigspolitiske vanskeligheder forstærkes af de mange udenrigspolitiske problemer, hvor både Irak-situationen, det belastede forhold til Syrien og det problematiske spørgsmål om resolution 1559 synes langt fra en løsning.
De mange attentater og bombesprængninger understreger alvoren i Libanons svære aktuelle situation. Hertil kommer en mere end anspændt national økonomi, hvor både den offentlige gæld og landets importoverskud udviser enorme tal, der i lang tid fremover må formodes at virke som betonklodser om fødderne på landets forsøg på at få væksten i gang. I den forbindelse er en hensygnende turistindustri et meget stort problem.

Det er som om sporene fra borgerkrigen igen er blevet tydeligere i Libanon. Libanons skæbne har de sidste 15 år i stor grad været knyttet til to helt forskellige fænomener. På den ene side den syriske dominans og på den anden side genopbygningsprocessen, i hvilken Hariri har spillet en central rolle.

Mordet på Hariri, i sig selv en tragedie, så en overgang ud til at kunne føre til national forsoning og politisk konsensus - ikke mindst på baggrund af den syriske tilbagetrækning, der fulgte i månederne efter. De dramatiske begivenheder synes imidlertid at føre så megen intern uro og splittelse med sig, at udviklingen siden valget $i$ Libanon indtil videre ligner et tilbageskridt.

Peter Seeberg, lektor, ph.d., Centerleder/ studieleder, Center for Mellemøststudier, Syddansk Universitet 